\title{
THE PURPOSE OF THE WILDERNESS AND CELL IN THE PSYCHOLOGICAL SHAPING OF THE MONK
}

\author{
Ph.D. Candidate Florin ȘTEFAN, \\ Faculty of Orthodox Theology „Justinian the Patriarch”, University of Bucharest, \\ ROMANIA, \\ E-mail: florinstefan@gmail.com,
}

\begin{abstract}
Anachoreism is a fascinating feature of Eastern monasticism. Many of the ascetic treatises, and especially the philocal collection, come from the heroic world of the anchorite monks who lived in uninhabited territories, wild but, above all, desert places. From the first centuries of the Christian Church, there are emblematic figures of the anchorite monk in the Egyptian space, who retreated to the desert, such as St. Paul of Thebes, the first Egyptian hermit known by name. The premise from which our study starts is that the geographical places chosen by the Christian anchorites, in this case the desert, the mountain, the forests, the isolated places, the caves, etc., predispose them to some psychospiritual transformations that they do not it could acquire (easily, or ever) in a very populated and stirred space. We have chosen for analysis and interpretation two habitats very common in the writings of the Desert Fathers: the desert (desert) and the cell. These two "special" spaces denote some characteristics that imprint special features in the psychology and personality of the needy. Therefore, the main purpose of this article is to present the psychological and practical significance of the retreat of anchorites in the desert and in the cell, respectively, proving, at the same time, that loneliness is for the Fathers of the desert, the element without which it would not have achieved so much spiritual performance in the inner space.
\end{abstract}

Keywords: anchorage; Fathers of the wilderness; psychic and spiritual transformations; loneliness; spiritual performances;

\section{INTRODUCTION}

The man who has reached the high steps of prayer can also pray in the middle of a public square without feeling disturbed, but, in contrast, the one with the scattered mind cannot pray even in the middle of the desert, where he does not see or hear any man. However, vigilance and prayer are practices that require both psychophysical training and a favorable spatial framework. To enter a deep inner state, the prayer needs a specially arranged place, sheltered from bustle of the world. Otherwise, what would be the point of Christ's exhortation: "But when you pray, enter into your room and shut the door and pray to your Father" ${ }^{1}$. Although the space of the place of worship, the church, remains the holiest place on earth because on the table of the Holy Altar is celebrated even daily (in monasteries and some parish churches) the Divine Liturgy, in which the Holy Eucharist is celebrated, however, we can note that, in the history of Christianity, the anchorites chose, with predilection, certain geographical places, such as the desert, mountain, forests, isolated

${ }^{1}$ Mt. 6, 6 
places, caves (from here we have so many localities or eponymous places), and even cemeteries (St. Antony the Great stayed in a tomb for many years), the garden, the pillar, etc., looking for the Hesychia, the prayer of the mind, severe asceticism, all from the desire to unite with God and to transfigure his psychosomatic function.

Assaulted both by the bustle and the noise of the world and by the sins of the society in which they lived, some Christians came out of the midst of the cities, looking for "special" places to devote themselves entirely to the real and profound intimacy with God. These, called anchorites, monks, loners, Hesychasts, "arranged" (we could say they sanctified) more "special" places, sometimes near the places of origin, but, most often, far from them, in the desert, in uninhabited territories and wild places. Because the human foot had not stepped on "dead leather shoes" in those spaces, they had a "cleaner" air, less poisoned by people's words, habits, and evils. The Grace descended through the prayers and asceticism of the hermits, made these places desolate, a heavenly Jerusalem, filled with the fragrance and presence of God. This spiritual reality led Benedicta Ward to state, in the Introduction to her prestigious work, Historia Monachorum, that anchorites can be compared to trees that purify and oxygenate the atmosphere, through their presence and prayers ${ }^{2}$.

The Christian ascetic literature highlights the desert and wilderness as scenes on which they are transposed into metaphysical dramas and psychological experiences difficult to intuit. The purpose of this article is to discover the psychological and practical significance of the retreat of anchorites in the desert, respectively in the cell, proving, at the same time, that loneliness is for the Fathers of the desert, the element without which it would not have achieved so much spiritual performance in the inner space. The desert, the cell, the mountain, and the other places mentioned are cataloged as spaces favorable to ascetic work and inner spiritual evolution. In association with contemplative practices, these places are appreciated as life generators ${ }^{3}$.

\section{THE WILDERNESS}

From the beginning, we must emphasize that the desert does not only designate empty places, unfit for life, but it means, in general, all those places uninhabited by people, "wild" places. Even though anachronistic Christian monasticism has its origins in the desert of Egypt, yet when we speak of the Desert Fathers and Christian anchorites, we do not think that they lived only in places full of sand, unfavorable to life. In this sense, the Egyptian desert was for Christians in North Africa, oppressed by wars, persecutions, etc., which were the forests and mountains for Romanians in times of hardship, a place of refuge, rescue ${ }^{4}$. But in our study, we will analyze the characteristics of the desert wilderness and the psychological implications of Christian anchorites.

The desert or wilderness holds a special place in biblical, Old, and New Testament history. Hebrew books treat this space as a totally unsuitable habitat for crops ${ }^{5}$. In the îbri conception, the desert had a dual connotation: on the one hand, it was considered an evil

\footnotetext{
${ }^{2}$ Benedicta Ward, Lives of the Desert Fathers: The Historia Monachorum in Aegypto, London and Oxford: Mowbray, 1980, p. 12.

${ }^{3}$ Cf. Meredith McGuire, Lived Religion: Faith and Practice in Everyday Life, NY: Oxford, New York, 2008, p. 52.

${ }^{4}$ Pr. Vasile Răducă, Monahismul egiptean. De la singurătate la obște, Ed. Nemira, București, 2003, p. 69.

${ }^{5}$ The Hebrew words 'midbar', 'arabah', 'tsiyyah', 'tohu', 'chorbah', 'yeshimon', 'eremia' and 'eremos' have a common meaning in opposition to the land arranged and worked. (George Williams, Wilderness and Paradise in Christian Thought: The Biblical Experience of the Desert in the History of Christianity and the Paradise Theme in the Theological Idea of the University, Harper and Bros, New York, 1962, p. 12)
} 
space, and on the other hand, a space of the revelation of the epiphanies and the divine covenant $^{6}$. The children of Israel did eat manna in the wilderness for forty years. Some of the prophets, such as Elijah, Elisha ${ }^{7}$, or John, the Forerunner of the Lord $^{8}$, went into the wilderness to worship the Lord. Also in the New Testament, there is talk about the Savior's exits into the wilderness, sometimes accompanied by disciples ${ }^{9}$, sometimes led by the Holy Spirit, where he lived "with wild beasts" ${ }^{10}$ and was "tempted by the devil" ${ }^{11}$ Episodes of exorcism are told in the Gospels, the demons being cast out by the Savior in the desert or in desolate places ${ }^{12}$. Thus, the desert still appears like an empty territory, harassed by demons and evil energies, "a place of trial" ${ }^{13}$. The wilderness is frightening not so much by the fact that it's the equivalent of the ocean on land, but especially by the fact that it conveys great loneliness and desolation, being considered a "land of death" ${ }^{14}$. The Arabic word used (dry valley) suggests very well what the desert lands were like ${ }^{15}$.

In classical pre-Christian literature, the figure of the hermit can be associated with the legend of the Truth that flees from corrupt cities and the imposture of the people, preferring solitude in the desert ${ }^{16}$. Authors such as St. Clement of Alexandria, Origen, St. Basil the Great, St. John Cassian, etc. would talk about the contrast between the purity of the air, the life in the deserted places, and the moral misery of urban life ${ }^{17}$. But early Christian asceticism, inspired by the Holy Scriptures and threatened by the social realities of the time, manages to give the desert special importance and a special significance, ${ }^{18}$ so that the uncultivated, sandy, rocky and uninhabited desert becomes an extremely valuable space for

\footnotetext{
${ }^{6}$ Associated with the curse, exile or death (Num. 20, 4-5; Deut. 1, 19; Is. 21, 1; Ier. 2, 6), wilderness is also a place of refuge, purification, divine alliance and the birth of a people (Ieș. 3, 2; 19, 1-20; Deut. 32, 10; Cânt. 3, 6; Ps. 55, 7; Ier. 9, 1) .

${ }^{7}$ IV Reg. 2, 25

${ }^{8}$ Cf. Matei 3, 3

${ }^{9}$ Lc 9,10 .

${ }^{10}$ Mc. $1,12-13$

${ }^{11}$ Mt. 4, 14.

${ }^{12}$ Mt. 12, 42 .

${ }^{13}$ Andrei Pleșu, Despre îngeri, Ed. Humanitas, București, 2003, p. 144.

${ }^{14}$ Since ancient times, the fertile land of the Nile Valley was attributed to the god of life, Osiris and Horus, his son, and the endless desert, devoid of any potential of existence, on both sides of the valley of this river, was considered to belong to Seth, the god death (Lucien Regnault, Viața cotidiană a Părinţilor deşertului in Egiptul secolului IV, trad. diac. Ioan I. Ică jr, Ed. Deisis, Sibiu, ${ }^{3} 2013$, p. 31). In fact, classical Greek and Roman culture identified piety with the cult service of the city and invested the places in the wild with a negative connotation, which lacked the presence and protection of the gods: "The important gods were the patrons of urban settlements, and exile threatened to loss the relationship with these deities, rather than promise it" (Adler, Judith, „Cultivating Wilderness: Environmentalism and Legacies of Early Christian Asceticism”, in:

Comparative Studies in Society and History, XLVIII (2006), 1, pp. 4-37, p. 11).

${ }^{15}$ Jean Brémond, Părinții pustiei, introducere şi comentarii traduse, din limba franceză, de Marinela Bojin, Nemira, București, ${ }^{2} 2010$, p. 141.

${ }^{16}$ André-Jean Festugière, La Révélation d'Hermès Trismégiste, vol. 1, Librairie Lecoffre, Paris, 1950, pp. 45 66; Diogenes Laertius, Lives of the Philosophers, ed. A. Robert Caponigri, Regnery, Chicago, 1969, p. 48.

${ }^{17}$ The association of the desert with hermit peace had a well-marked place in the ascetic traditions of South Asia, known to Roman Egypt (vezi Olivelle J. Patrick, "Village vs. Wilderness: Ascetic Ideals and the Hindu World", in: Austin Creel, Vasudha Narayan (eds.), Monastic Life in the Christian and Hindu Traditions, The Edwin Mellen Press, Lewiston, 1990, pp. 125-161).

${ }^{18}$ For more details on this topic, see: Antoine Guillaumont, Claire Guillaumont, „La conception du désert chez les moines d'Egypte", in: Revue de l'Histoire des Religions, CLXXXVIII (1975), pp. 3-21.
} 
Christian hermits ${ }^{19}$, they create a truly spiritual and intellectual universe (thousands of manuscripts and countless pages have been written here containing a deep spirituality).

In the middle of the third century, during Decius persecution, many Christians fled to the desert of Egypt to escape martyrdom and save their lives. For these Christians, nourished by the spirit of Scripture and the example of the martyrs, the desert was not so frightening, on the contrary, they considered their experience to be similar to one of the Jewish people in the time of Moses, who was led by God out of Egyptian bondage in the desert and later taken to the Promise Land ${ }^{20}$. Primary Christian literature identifies the empty space, the wilderness in general, with a framework out of the normality of human existence, where, on the one hand, the animal, the irrational, and the demonic appear, and on the other hand, the sublime, the suprarational and the angelic ${ }^{21}$. Judith Adler argues that from the 4th to the 7 th century, the desert received new meanings ${ }^{22}$. Thus, the meaning of the wilderness came to equate less with "the nature of the earth than with the general concept of ascetic retreat" 23 . With the migration of Christians to these unknown and repulsive places, the word desert begins to be associated, not so much with a geographical space difficult to access and unfavorable to life, but especially with "a space of spiritual experience, change, and transformation of the ascetic" $^{24}$.

The desert territories had a uniform and homogeneous appearance, shapes stretched linearly to the distances of the horizon and monotonous colors, black-reddish or yellow ${ }^{25}$, which invaded the entire retina of the eye, favoring a deepening of the spiritual life. Looking for an arid space, bare and empty of any landscape, the Desert Fathers imprinted these features on their own minds: clarity, homogeneity, the emptiness of the imaginary. The "empty" wilderness was indicated as an ideal place to explore and cultivate the "inner" spaces of the soul. In this sense, the observation of Judith Adler takes shape: The saints and deserts of hagiographic literature mirror one another: "pure", "rugged," "terrible," "mountainous" wilderness offers the very image of the mind of a holy man, whose ascribed qualities, in turn, sanctified real geographical spaces",26.

\footnotetext{
${ }^{19}$ From the Greek "eremia" - empty place; loneliness (see James E. Goehring, "The Encroaching Desert: Literary Production and Ascetic Space in Early Christian Egypt", in: Journal of Early Christian Studies, I (1993), 3, pp. 281-296, p. 281).

20 "Wilderness was a foundational premise of Israel's cult [...] The Lord of the Jews reveals His name, shows His face, dictates His laws, performs His acts in the desert; His chosen people wander in the wilderness for a generation; His prophets withdraw from sinful cities, returning to the desert to renew their relationship with Yahweh" (J. Adler, "Cultivating Wilderness... ", p. 13).

21 "On the one hand, the desert is a place of beauty, [..] on the other hand, the desert becomes a continuous challenge on the edge of the inhabited world, a place of extreme experience" (Pr. Daniel Benga, "Tipuri de spaţii teofanice. Câteva schiţe de fenomenologie”, în: Adrian Lemeni, Adrian Sorin Mihalache (eds.), Realitatea şi Semnificația spațiului, Ed. Basilica, Bucureşti, 2014, pp. 261- 275, p. 267).

22 "Between the fourth and seventh centuries, desert, until very recently simply synonymous with empty, uncultivated wild lands, became established as a principal character, [...] in human metaphysical dramas. [...] as sanctity's distinctive habitat: penitential, sacramental, redemptive, self-re-creative space of the first order" (J. Adler, „Cultivating Wilderness...”, p. 10).

${ }^{23}$ Tim Vivian, Histories of the Monks of Upper Egypt and the Life of Onnophrius. Cistercian Publ., 2000, pp. 18-26, apud James E. Goehring, "The Dark Side of Landscape: Ideology and Power in the Christian Myth of the Desert", in: Journal of Medieval and Early Modern Studies, XXXIII (2003), 3, pp. 437-451, p. 446.

${ }^{24}$ Pr. D. Benga, "Tipuri de spaţii teofanice...”, p. 267.

${ }^{25}$ The visible and sharp separation between black (fertile land) and red (desert) in the Egyptian landscape provides the natural ingredients of this natural ecological division, with reflections in the spiritual separation of the ascetic from the world. (cf. J. E. Goehring, "The Dark Side of Landscape..", p. 439).

${ }^{26}$ J. Adler, "Cultivating Wilderness..., p. 17.
} 
The Desert Fathers showed, par excellence, the deep meaning of the wilderness in Christian spirituality. They highlighted this wild space as an arena of spiritual struggle, as an experiment of human limits, as a space of interference between human and other forms of being.

The demons who had taken refuge in the wilderness were totally uncomfortable with the presence of the ascetic saints, who stormed the entire wilderness of Egypt ${ }^{27}$. Monks often took refuge in the "deep" desert (for example, the Sketis desert) out of a desire to climb the not at all gentle steps of asceticism and spiritual struggles. In this regard, the wilderness was the "limit test" of the monastic, hermit vocation. Therefore, the concept of "wilderness" was increasingly synonymous either with the space possessed by demons and evil forces, or with the privileged, clean space in which the divine epiphanies were revealed. Alistair McGrath testifies to this fact when arguing that "a world without wilderness might be one whose demons had been routed from their last stronghold by enterprising Christian pioneers, or one in which the empty spaces, chosen by God for epiphany and alliance, or by men for penitential purification, self-recreation and communion, had been irreparably destroyed by $\sin ^{\prime 28}$. In the natural setting of the desert, there appears, with the presence of the monks, a separation, a rift in the ontic space, as "the material desert becomes a paradise of the spirit" $^{29}$.

The Philocalys, writings with a pronounced ascetic character, describe the desert as that experiential spiritual laboratory where the Fathers came intending to empty themselves and with the intention of spiritual struggle. St. Isaac the Syrian reveals to us that the holy angelic powers are seen by the worthy, and bring them discoveries (visions), in places more desolate and more distant from people ${ }^{30}$. St. Isaac also claims that God's work is shown mainly in the wilderness, the "land of peace" ${ }^{31}$, a fact confirmed in the 14 th -15 th century, by Calise and Ignatius Xanthopol Fathers, who would argue that God's work is obviously felt in the "peace land" and, in general, in places away from the disturbance of living with people $^{32}$. St. John the Ladder talks about the great battles that the hermits endure from demons, in the places of peace, emphasizing the fact that the latter were driven out into the wilderness by the Lord and they like to spend time in these arid places. Therefore, the

\footnotetext{
${ }^{27}$ Satan complained to Antony that the territory he ruled had diminished greatly because of the Christians: "So I have no place, no arrow, no city. They have become Christians everywhere. Finally, the desert was filled with monks" (Sf. Atanasie cel Mare, Viața Cuviosului părintelui nostru Antonie, trad., introd. și note Pr. Prof. Dumitru Stăniloae, în PSB, 16, Ed. IBMBOR, București, 1988, p. 217).

${ }^{28}$ Alistair McGrath, The Reenchantment of Nature: The Denial of Religion and the Ecological Crisis, New York: Doubleday, 2002, apud J. Adler, "Cultivating Wilderness...”, pp. 29-30

${ }^{29}$ Eucherius din Lyon, De laude eremi, 39, apud J. E. Goehring, "The Dark Side of Landscape...”, p. 447; The desert becomes, in fact, a heaven on earth, a place that "holds [the saints] as in their mothers' laps," that protects them from Satan as a strong-walled sheepfold guards the sheep, that dispenses with the need of civil laws because "the obligations of eternal life are observed more exactly," where "no sound is heard ... save the voice of God" (Eucherius din Lyon, De laude eremi, 34-37, apud J. E. Goehring, "The Dark Side of Landscape...”, p. 447). Translations of this writing: Eucherius of Lyon's De laude eremi este editat de Karl Wotke, Sancti Eucherii Lugdunensis Epistula de laude heremi, Corpus Scriptorum Ecclesiasticorum Latinorum, Prague, 1894, pp. 178-94; and Salvator Pricoco, Eucherii De laude eremi, Catania: Centro di Studi Sull'Antico Cristianesimo, 1965; It is translated into English by Charles Cummings, "Praise of the Desert: A Letter to Hilary of Lérins, Bishop, by Eucher of Lyons”, in: Cistercian Studies, XI (1976), pp. 60-72.

${ }^{30}$ Sf Isaac Sirul, Cuvinte despre nevoință, Despre deosebirea lacrimilor, în Filocalia, vol. X, trad., introd. și note de Pr. Prof. Dumitru Stăniloae, Ed. Humanitas, București, 2008, p. 396.

${ }^{31}$ Idem, Cuvinte despre nevoință, Cuv. XIX, în Filocalia, X, p. 93.

${ }^{32}$ Calist și Ignatie Xanthopol, Cele 100 de capete, 85, în Filocalia, vol. VIII, trad., introd. și note de Pr. Prof. Dumitru Stăniloae, Ed. Humanitas, București, 2009, p. 165.
} 
demons are terribly at war with the monks to make them return to the world ${ }^{33}$. It is very relevant, in this regard, the moment when Antonie the Great came to the desert when he was greeted with hostility by demons who were trying with all their might to get him out of this territory: "Leave these places that belong to us. What is between you and the wilderness? You do not receive our temptations" ${ }^{34}$. Most of the monks came to the desert armed with an extraordinary spiritual force. Known as the realm of demons, the unseen war had become much more open and with much stronger bursts. If in society the demon worked through human relations, in the desert the monk fought face to face with him.

Nevertheless, the monks believed that they could more easily acquire virtues and redemption if they left the middle of the world and fled into the wilderness because here they could dedicate themselves to prayer and serve $\operatorname{God}^{35}$. Thus, the refugees in the deepest desert felt comforted by its harshness, considered the most appropriate environment in which they can detach themselves from the body and life pleasures. In this regard, the conversation between ava Avram and ava John Cassian is relevant: "We could have placed our cells on the Nile riverbed, to have water for flowers, so we won't be forced to bring it on our shoulders from a distance of four thousand steps; [...] in which there is no lack of trees laden with fruits, beautiful gardens and we would all be in abundance [...] But turning our face from all this and despising all the pleasure of this world, we feel delighted by the harshness of the wilderness, [...] and the eternal comforts of the Spirit" ${ }^{36}$. Therefore, from the hermits perspective, the desert is the perfect place where they can practice their human virtues and limits to imitate Christ the Savior. They were willing to resist fearlessly from hunger and distress, considering their temptations much easier to bear compared to those in cities and towns ${ }^{37}$. Just the thought that they could become imitators of Christ (before they began the mission of preaching in the Jordan, they retreated into the wilderness for forty days and nights) unleashed in them a feeling of sublime joy ${ }^{38}$.

The longing to spend with God and the search for union with Him in the contemplation mysteries were the motivations that aroused the anchorites to leave far from the world, in the "Peace Land". Thus, when St. Gregory of Sinai asks the Pious Maximus Cavsocalivitus whether he was entitled, as a result of Jesus' prayer, to receive any ekstas, any "self-denial" or at least a divine pretense, he replied, "O Father, that's why I went to a deserted place" ${ }^{39}$.

These living people of the experience of Christ came to the wilderness to empty themselves, rejecting any imprint of things in the world. Thus, the desert environment became the pure mind archetype, emptied of passions. The pious Nichita Stithatul associated the neglecting of one's own will and the abandonment of bodily wills with a "leaving into the wilderness of passions" 40 , and Ilie Ecdicul would say that not working for passions is a "stay

\footnotetext{
${ }^{33}$ Sf. Ioan Scărarul, Cartea despre nevoințe, Cuv. XV, 59, 60, în Filocalia, vol. IX, trad., introd. și note de Pr. Prof. Dumitru Stăniloae, Ed. Humanitas, București, 2011, p. 215

${ }^{34}$ Sf. Atanasie cel Mare, Viața Cuviosului Părintelui nostru Antonie, XIII, în PSB, 16, p. 200.

${ }^{35}$ Cf. Monahul Augustin, Prolog la prima ediție, în Filocalia, vol. XII, trad., introd. şi note de Pr. Prof. Dumitru Stăniloae, Ed. Humanitas, București, 2009, p. 11, p.15.

${ }^{36}$ Sf. Ioan Casian, Convorbiri duhovnicești, Partea a III-a, XXIV, Convorbirea Pr. Avraam. Despre mortificare, II, în PSB, 57, trad. prof. Vasile Cojocaru și prof. David Popescu, Ed. IBMBOR, București, 1990, p. 725.

${ }^{37}$ Sf. Isaac Sirul, Cuvinte despre nevoință, Cuv. XXVI, în Filocalia, X, p. 132.

${ }^{38} \mathrm{St}$. Isaac the Syrian compares the feeling of joy of hermits who go to deserted places with the feelings of the bird Herodius, who lives in deserted areas, protected from the presence of people (Cf. Sf Isaac Sirul, Cuvinte despre nevoință, Cuvinte despre nevoință, Cuv. LXXIII, în Filocalia, X, p. 331).

${ }^{39}$ Apud Teofan, Viața Cuviosului Maxim Cavsocalivitul, în Filocalia, VIII, p. 471-472.

${ }^{40}$ Nichita Stithatul, Cele 300 de capete despre făptuire, 75, 76, în Filocalia, vol. VI, trad., introd. şi note de Pr. Prof. Dumitru Stăniloae, Ed. Humanitas, București, 2008, p. 213.
} 
in the wilderness" ${ }^{41}$. This philocaly author also states that entering the wilderness would be equivalent, in terms of contemplative prayer, to the first two steps, which have as their objective the reason feeling ${ }^{42}$. The fact that the desert offers the mind a therapeutic framework for healing the passions, is strengthened, much later, by the Vasile monk from Poiana Mărului († 1767), who, interpreting the writings of St. Gregory of Sinai, specifies that the mind will taste the sweetness much more spiritual when he closes it in the wilderness (in solitude, isolation) ${ }^{43}$. Commenting on this text, Fr. Dumitru Stăniloae states that the desert outside is a face of thoughts emptying ${ }^{44}$. Then the very human heart becomes an "inner land of peace" 45 .

From what has been said so far, we understand that the desert appears to the spiritual man as a world revealed by the "deceptive ornamentation of its social «adornments»" 46 , but precisely this extreme ambiance, of uninhabited, uncultivated, arid, dry, wild space, makes it face to face with himself. The frightening expanse and silence, intrinsic qualities of a kid, have a wholesome effect on the mind. In a setting devoid of many outside stimuli (the desert), the hermit only has to dive into himself and create inside a "sanitized" environment, purified and free from disorder, a proper environment leading to contemplative calm. Descended into the deserted space of the heart, the anchorite is "compelled to go deeper and deeper on the path of purification of the heart, and [...] to gradually discover all the secrets of God's ways" ${ }^{47}$. According to Fr. Ioan Teșu, in order "to become «spiritual», the Christian needs to live the «experience of the wilderness», to experience in his life this dimension of the spiritual, whether it is an external or an internal desert" 48 ."Emptiness" means, therefore, detachment, despair and stripping off everything that has "grounded" us.

The hermit has a fascinating dose of courage compared to the ordinary man, for the latter, the desert being "the territory of a great loneliness", especially when he remains with himself ${ }^{49}$. In addition to courage and spiritual strength, the hermit also has a great inner power of conversion, through the very severe ascetic discipline he assumes in the uninhabited and unfavorable places of life. It is a struggle for life, but it is not limited to biological life. Referring to the ascetic life in the desert, Andrei Pleşu resembles it to military training and techniques, and even more, to the alarm state, specific to the state of war ${ }^{50}$. Paul Evdochimov will say that the desert is a real "anthropological laboratory" ${ }^{51}$. We are fascinated by the multitude of people transfigured in the wilderness, in this city of angels ${ }^{52}$,

\footnotetext{
${ }^{41}$ Ilie Ecdicul, Culegere din Sentinețele înțelepților, Capete despre cunoștință, 125, în Filocalia, vol. IV, trad., introd. și note de Pr. Prof. Dumitru Stăniloae, Ed. Humanitas, București, 2009, p. 269.

${ }^{42}$ Ilie Ecdicul, Culegere din Sentinețele înțelepților, Capete despre cunoștință, 125, în Filocalia, IV, p. 269.

${ }^{43}$ Preacuviosul Vasile de la Poiana Mărului, Cuvânt înainte sau călăuză, în Filocalia, VIII, p. 515.

${ }^{44}$ Filocalia, VIII, nota 1023, p. 515.

${ }^{45}$ Filocalia, VIII, nota 420, p. 165.

${ }^{46}$ Cf. L'Ermitage. Spiritualite du Desert..., pp. 4-5, apud A. Pleșu, Despre îngeri..., p. 144.

${ }^{47}$ L. Regnault, Viața cotidiană a Părinţilor..., pp. 17-18.

${ }^{48}$ Pr. Ioan C. Teșu, Teologia necazurilor și alte ințelesuri, Ed. Christiana, București, 1998, p. 19.

${ }^{49}$ Cf. L'Ermitage. Spiritualité du Desert..., pp. 4-5, apud A. Pleșu, Despre îngeri..., p. 143.

50 "The asceticism of the fighter in the desert [...] aims to ensure the human aggregate a front condition. Control of physical and mental energies, reduction of "consumption", perfect mastery of the body and emotions are the minimum endowments of an effective "fighter"" (A. Pleșu, Despre ingeri..., p. 146).

${ }^{51}$ Paul Evdokimov, Femeia şi mântuirea lumii, prefaţă de Olivier Clément, trad. Gabriela Moldoveanu, Asociaţia filantropică medicală creştină Christiana, Bucureşti, 1995, p. 66.

${ }^{52}$ Sf. Isaac Sirul, Cuvinte despre nevoinţă, Cuv.V, în Filocalia, X, , p. 46.
} 
where they became gods by grace ${ }^{53}$. For the philocaly man, the kid remains that stadium in which he always spends flaming, ready for battle, like a true soldier of Christ, who achieves amazing metaphysical victories ${ }^{54}$.

\section{THE CELL}

In the conditions of the desert population, the monk's requirement to dedicate himself to prayer and spiritual life no longer seemed achievable ${ }^{55}$. For example, Nitrian monasticism would expand its community to the deep desert, which will be called Kellia, because many monks had come to Nitria and there was no peace. Under these conditions, one of the requirements of the rulers and advisors was that their disciples remain in the cell ${ }^{56}$. The monks received this obedience, to remain in the cell for days, weeks, or even longer periods of time. The cell in the sketic desert (Sketis, in Greek) designated, as today on Mount Athos, a house with at least two rooms, surrounded by a brick wall. Many times, in the courtyard of the cell, a fountain, and a vegetable garden was arranged. In a cell, several brothers usually lived, in which case the cell had several rooms ${ }^{57}$. But we know the case of St. Macarius the Alexandrian, who, eager to try many forms of asceticism, built several types of cells in the desert, of different sizes. Some of the cells had no windows, and one was so narrow that he could not stretch his legs ${ }^{58}$. In the following lines, we want to emphasize, especially, the importance of the cell space for the psychology and spiritual evolution of the anchorites.

Staying in the cell fulfills, in a concrete way, the advice: "Enter your pantry..." ${ }^{59}$, proving to be the most suitable place for prayer. In this small and dimly lit cell space, the ascetic's lifestyle includes ritual activities that sanctify him. Certainly, the essential activity of the monk in the cell was prayer. She accompanied and crowned any activity. Therefore, Ava Isaiah summarizes, in a few words, the main activities that the monk performs inside the cell: the hands work (rucodelia), meditation and prayer $^{60}$. Therefore, most of the time spent in the cell was dedicated to these few activities. The limited space of the cell encloses the mental space of the prayer. This closure, censorship of the body in the cell becomes an exercise in the protection of thoughts of the mind. About this fact St. John Cassian says: "No one can avoid this waste of thoughts and worries if he has not closed his body and soul

\footnotetext{
53 "For in the wilderness many fathers lived the life of angels. [...] prophets who have reached a divine state" (B. Ward, Lives of the Desert Fathers..., p. 49)

${ }^{54}$ Cf. Sf. Ioan Casian, Despre aşezămintele mînăstireşti şi despre tămăduirile celor opt păcate principale, Introducere. Viaţa ascetului e o luptă, în $P S B, 57$, p. 61.

55 "In the depths of the wilderness, about ten miles from Nitria, was the place called Kellia, because it was full of cells far apart from each other, at such a distance that they could not recognize each other, nor be seen with their eyes, not even to hear their voices clearly" (J. Brémond, Părinții pustiei..., p. 142).

56 "Close the door of the cell and the door of the tongue to the body, and the door of the spirit (evil) inside" (Sf. Ioan Scărarul, Carte despre nevoințe, Cuv. XXVII, 17, în Filocalia, IX, p. 337. This text is also taken over by Calist and Ignatie Xanthopol Fathers (Cele 10 de capete, 47, în Filocalia, VIII, p. 96). Another well-known text, which emphasizes the power of wisdom conferred by retreat into the cell, is rendered by St. Simeon the New Theologian and later by Peter Damaschin, of ava Moise: "Sit in your cell and it will teach you all of you " (Sf. Simeon Noul Teolog, Metoda Sfintei rugăciuni. Despre al treilea fel de rugăciune, în Filocalia, VIII, p. 464; see also, Sf. Petru Damaschin, Învățături duhovnicești, în Filocalia, vol. V, trad., introd. și note de Pr. Prof. Dumitru Stăniloae, Ed. Humanitas, București, 2009, p. 65).

${ }^{57}$ Pr. Vasile Răducă, Monahismul egiptean. De la singurătate la obște, Ed. Nemira, București, 2003, p. 110.

${ }^{58}$ More details about the life of St. Macarius the Alexandrian, see Paladie, Istoria Lausiacă (Lavsaicon), 18, trad., introd. și note de Pr. Prof. Dumitru Stăniloae, Ed. IBMBOR, București, 1993.

${ }^{59}$ Mt. 6, 6.

${ }^{60}$ Isaia Pustnicul, Douăzeci și nouă de cuvinte, IX, 2, în Filocalia, XII, p. 94.
} 
eternally between the walls of his cell" ${ }^{61}$. In this sense, Ava Filimon confesses that, since he came to the Hermitage, he hasn't allowed the thought to leave the cell and had no other form of thought, apart from the fear of God and future judgments ${ }^{62}$. St. Isaac the Syrian also prescribes the monks' manner to spend time in the cell solitude ${ }^{63}$. This cell space was a mind shell in which he protected his purity in relation to the deeds, the words, the things of the world in general. St. Isaac argues the need to remain alone in the cell because, by not making contact with the evil deeds of men, his perception of men will become so optimistic and spiritual that he will consider all of them saints ${ }^{64}$. In addition, Calise and Ignatius Xanthopol recall that staying in the cell has a well-defined role in the monk's conduct; inside the cell, he guards his life in the spirit of discoveries (contemplations) ${ }^{65}$. These words are reminiscent of what St. John the Ladder had confessed long before, namely, that inside the cell is the house of knowledge (contemplation) ${ }^{66}$ and that he who rests in the cell, closes the nonphysical body in the body house ${ }^{67}$.

For most of the Philocaly Fathers, staying in the cell involves taking care of one's own repentance, being mindful of prayer, and shedding many tears ${ }^{68}$. When it comes to meditation, the subject is quite broad, as shown by Theodore of Edessa, when he urges the monk to first gather his mind and imagine the moment of death, than to meditate on the ephemerality and vanity of the world and on the judgment of the Savior, where he will receive accusations from the demons, who here on earth have instilled temptations in his thoughts and words ${ }^{69}$. Peter of Damascus urges that meditation starts from what surrounds him. For example, seeing the darkness in the cell, associate it with the darkness of the deep ${ }^{70}$.

However, staying in the cell for an indefinite period has whole psychology in the substratum. The most experienced ascetics (the elders of the wilderness) knew that many of the disciples who had come very enthusiastically to this hardship place to find God were leaving in a very short time when they saw what a struggle it must be in this environment. The elders knew that for monks tempted by spatial freedom and fellowship, staying in the cell was a hard test to pass. Rare were the hermits, such as Ava Isaiah, who, founding a monastery in Gaza, locked himself in the house and didn't want to see anyone but Peter, the disciple's leader, through whom he communicated various answers to others ${ }^{71}$.

This exercise of staying in the cell involves many downs, as the hermit experienced periods of anxiety, boredom, and disgust, and the desire to get out of the cell took shape inside him, finding seemingly very well-intentioned reasons to go out and visit other brothers. The isolation required was, in this case, an antidote to "vagrancy" that tortured the hearts of many who came to the wilderness. This impediment makes Evagrie the Ponticus

\footnotetext{
${ }^{61}$ Sf. Ioan Casian, Convorbiri duhovnicești, Partea a III-a, XXIV, Convorbirea Pr. Avraam. Despre mortificare, III, în PSB, 57, p. 726.

${ }^{62}$ Ava Filimon, Cuvânt foarte folositor, în Filocalia, IV, p. 158.

63 "... in your cell [...] always deal with the contemplation of tropes and catechisms and with the thought of death and the hope of the future" (Sf. Isaac Sirul, Cuvinte despre nevoință, Cuv. LXVII, în Filocalia, X, p. 311).

${ }^{64}$ Sf. Isaac Sirul, Cuvinte despre nevoință, Cuv. LVIII, în Filocalia, X, p. 273.

${ }^{65}$ Sf. Calist și Ignatie Xanthopol, Cele 100 de capete, 28, în Filocalia, VIII, p. 64.

${ }^{66}$ Sf. Ioan Scărarul, Cartea despre nevoințe, Cuv. XXVII, 10, în Filocalia, IX, p. 336.

${ }^{67}$ Sf. Ioan Scărarul, Cartea despre nevoințe, Cuv. XXVII, 5, în Filocalia, IX, p. 335.

${ }^{68}$ Simeon Evlaviosul, Capete morale, 17, în Filocalia, VI, p. 91.

${ }^{69}$ Teodor al Edessei, Una sută capete, 57, în Filocalia, IV, p. 197.

${ }^{70}$ Sf. Petru Damaschin, Învățături duhovnicești, Cuv. 22, în Filocalia, V, p. 222.

${ }^{71}$ Monahul Augustin, Prolog la ediția întâi, în Filoclaia, XII, p. 31.
} 
say that the lust for wandering spoils the wicked mind and that the only means of correction is to stay in the cell ${ }^{72}$. St. John the Ladder points out that the unsaturated desire of some to blow the door of the cell predisposes them to lose everything they have gathered inside them, because, opening it, "closed birds fly" ${ }^{73}$. That these "birds" are a metaphor for naming the virtues, convinces us in the text of a footnote, which talks about the possibility of losing the virtues, acquired during peace, due to exits from the cell ${ }^{74}$. St. Isaac the Syrian says that the needy should not make a habit of receiving friends in the cell for the reason of kindness ${ }^{75}$. Other philocaly authors believe that time spent too much outside the cell becomes a very damaging behavior for those who want to calm down, having ontological effects: it takes away his grace, darkens his judgment, becomes insensitive to the divine ${ }^{76}$. Those who fell into such traps very often were the beginners of hardships. They were asked to stay in the cell and to avoid, as much as possible, any conversation and even any glance ${ }^{77}$.

"Staying in the cell" was more a disposition of the steadier soul, very determined in its ascetic effort. Therefore, the austerity of the cell involved a set of pre-established rules, which the ascetic imposed and strictly followed. For example, one of the rules was to eat as much as he could to fulfill his service, and as long as he didn't have to go out ${ }^{78}$. Ava Isaiah urges the monk to have a measure and a specific time when it comes to food ${ }^{79}$. As for other things, the ascetics were urged not to agonize over goods to bring to the cell, but to spend in poverty and lack of everything, lest they arouse any lust "for peace"80. Also, the pious Simeon, the teacher of St. Simeon the New Theologian, tells the Hesychasts to not keep anything outside in the cell, but the only objects they can have are a basket, a straw mattress and a coat ${ }^{81}$. By the fact that, inside the cell, the most common object is the matting, on which the ascetic prayed or slept ${ }^{82}$, it is necessary to interpret that the cell poverty represents the emptying of the "world spirit", the surrender of the material things that the monastic pretender assume.

On the other hand, staying in the cell was also a quintessential way to meet yourself. The monk had a frame that allowed him to introspect all the contents of his heart. Under the aegis of attention, he researches himself and knows his weaknesses, including the fact that he is not a formidable fighter with the devil ${ }^{83}$. The autogenic exercises of discipline represented for the monks locked in the cell a real ascetic school, they looking every day to better define

\footnotetext{
${ }^{72}$ Evagrie Ponticul, Schiță monahicească, 6, în Filocalia, vol. I, trad., introd. şi note de Pr. Prof. Dumitru Stăniloae, Ed. Humanitas, București, 2008, p. 47.

${ }^{73}$ Sf. Ioan Scărarul, Cartea despre nevoințe, Cuv. XXVII, 16, în Filocalia, X, , p. 346.

${ }^{74}$ Filocalia, IX, nota 873, p. 346.

${ }^{75}$ Isaac Sirul, Cuvinte despre nevoință, XXIII, în Filocalia, X, p. 118.

${ }^{76}$ Teodor al Edessei, Una sută capete, 56, în Filocalia, IV, p. 197.

${ }^{77}$ Calist Angelicude, Meșteșugul liniștirii, în Filocalia, VIII, pp. 333 - 334.

${ }^{78}$ Isaia Pustnicul, Douăzeci și nouă de cuvinte, 4, în Filocalia, XII, p. 55.

${ }^{79}$ Isaia Pustnicul, Porunci sau sfaturi ale lui Avva Isaia, 54, în Filocalia, XII, p. 245

${ }^{80}$ Sf Isaac Sirul, Cuvinte despre nevoință, Cuv. LXXXV, în Filocalia, X, p. 385.

${ }^{81}$ Simeon Evlaviosul, Capete morale, 15, în Filocalia, VI, p. 91.

${ }^{82}$ Sf. Ioan Casian, Așezăminte mănăstirești, Despre rânduielile celor ce renunță la lume, Cartea a patra, 13, în PSB, 57, trad. prof. Vasile Cojocaru și prof. David Popescu, Ed. IBMBOR, București, 1990, p. 147; vezi și Ava Agathon, 1, în Patericul Egiptean, Ed. Episcopia Ortodoxă Romană a Alba Iuliei, Alba Iulia, 2003, pp. 21-22.

${ }^{83}$ The words of ava Apollo, apud Sf. Ioan Casian, Cuvânt plin de mult folos. Către egumenul Leontie, în Filocalia, I, p. 134.
} 
their objectives in the spiritual evolution. In this sense, they searched every day, evaluating themselves concerning God and their fellow men ${ }^{84}$.

Irénée Hausherr is absolutely impressed by the Parents' patience who resisted and endured the conditions of a chamber, sometimes small, and by the courage with they faced the demon of akedia, which impelled their minds with instability, murmuring and disobedience ${ }^{85}$. One of those who sought solitude in modern times was Thomas Merton, who says that in the solitary crucible of the hermitage, he discovered other ways of being, another intimacy of his soul. He felt a new being reconfigured. He discovered a new "dwelling place of the self" in God ${ }^{86}$. Guillaume de Saint-Thierry, the author of a Treaty on life in solitude, associates, through wordplays, cella (cell) and caelum (sky), both coming from "celo" - to hide $^{87}$. Hence, since the small size of the cell isolates, closes, deprives of contact with the outside world, obstructs the area of relationship, drastically restricts freedom of movement and physical freedom, the gaze of the anchored ascetic goes more to heaven, where he finds infinite freedom for his spiritual ascension. More than likely, these characteristics of the cell (cell) were understood and lived by the saints of the prisons in the communist prisons, who made their way to heaven, following the patristic and philocaly model. Although they were forcibly isolated, they appropriated their anchoritic lifestyle and, thus, the gifts and charisms of old times have been seen in our actual times.

Therefore, characterized by complete silence and tranquility, the cell becomes the face of assumed loneliness, the shell in which man mortifies his bodily senses, to sharpen his spiritual ones. The cell was very well associated with a tomb ${ }^{88}$, from where the mind takes flight in the air of contemplation. It was the limited dimensions of the cell that allowed the monk to transcend into unlimited spiritual space.

\section{CONCLUSION}

The Christian anchorite or hermit chose the empty or wild places, the uninhabited places of people, out of the desire to dedicate himself to uninterrupted prayer and full communion with God. Of course, this choice was often based on additional reasons, such as the need for loneliness, the need to get away from the hustle, the chatter, the bad habits and the evils of people, and the compulsion to flee in the face of the persecutions to which the early Church has been under in the first centuries of its existence. The bare landscape or the unfavorable conditions of the wild, of the emptiness, become a mirrored image of the inner habitat of the ascetic. Outer hermitage is neither sufficient nor effective in the absence of inner loneliness. Poor landscape and fading colors of the wild environment can express the state of simplicity, modesty and authenticity to which the anchorite must adhere. The austerities of hermit life in the wilderness and in the cell do not suit everyone, so, we have highlighted some psychological aspects that these spaces propose them directly to those who decided to seek, firstly, loneliness and then the inner kingdom. The deep wilderness or the

\footnotetext{
84 "When we return to our cells, let us examine ourselves and find out what we have used or damaged" (Ava Dorotei, Diferite Epistole, 2, în Filocalia, IX, p. 553).

${ }^{85}$ Cf. Irénée Hausherr, "Direction spirituelle en Orient autrefois", in: Orientalia Christiana Analecta, CXLIV (1955), 1, Pont. Institutum Orientalium Studiorum, Rome, p. 78.

${ }^{86}$ Cf. Thomas Merton, "Dancing in the Water of Life", in: The Journals of Thomas Merton 5/1963-65, ed.

Robert E. Daggy, HarperCollins, San Francisco, 1997, p. 298.

${ }^{87}$ Marie-Madeleine Davy, „Le moine et l'ange en Occident au douzieme siecle”, in: L'Ange et l'Homme, col.

Cahiers de l'Hermetisme, Ed. Albin Michel, Paris, 1978, pp. 107-127, p. 112.

${ }^{88}$ Sf. Ioan Scărarul, Cartea despre nevoințe, Partea a II-a, 38, în Filocalia, IX, p. 352.
} 
places of hermitage correspond to our intimate depth, where it is necessary to settle the hesychia, the peace of thoughts and the absence of passions.

The philocal texts draw our attention to the fact that, due to the ascetic life, angels that the Christian hermits have acquired through loneliness and prayer, the desert itself undergoes ontological transformations, so that this wild space, unwelcome and unfavorable to life, becomes an oasis of angelic life, a city of monks, a home of angels. As the desert metamorphoses, man's inner darkness gives way to the revelation of the Tabor light. Therefore, the man who receives rich grace from God, spiritualizes, in addition to his nature, the space in which he lives. Hence the popular expression that "the man blesses the place". The spiritual man needs a particular space, different from the profane space, in which he can glimpse the landmarks of the future age and the mystery of the Kingdom of God. His existential imprint enters deep into the physical structure of the world, transfiguring itself with it.

Both the wild and the cell express a lonely, poor and "sanitized" place, a laboratory in which the anchorite creates the conditions for his own transfiguration. The demands of the environment predispose the mind and body of the monk to self-discipline, asceticism, concentration and contemplation. These spaces denote ontic and psychological implications that only those who experience them can understand. But from the descriptions of the Fathers, we deduce that such places, as they seem devoid of delight and bodily comfort, are so rich and nourishing to the soul.

\section{BIBLIOGRAPHY:}

[1] Adler, Judith, „Cultivating Wilderness: Environmentalism and Legacies of Early Christian Asceticism”, în Comparative Studies in Society and History, XLVIII (2006), 1, pp. 4-37.

[2]Sf. Atanasie cel Mare, Viața Cuviosului părintelui nostru Antonie, trad., introd. și note Pr. Prof. Dumitru Stăniloae, în $P S B, 16$, Ed. IBMBOR, București, 1988.

[3]Brémond, Jean, Părinții pustiei, introducere şi comentarii traduse din lb. franceză de Marinela Bojin, Ed. Nemira, București, ${ }^{2} 2010$.

[4]Creel, Austin, Narayan, Vasudha, (eds.), Monastic Life in the Christian and Hindu Traditions, The Edwin Mellen Press, Lewiston, 1990.

[5]Davy, Marie-Madeleine, „Le moine et l'ange en Occident au douzieme siecle”, in: L'Ange et l'Homme, col. Cahiers de l'Hermetisme, Ed. Albin Michel, Paris, 1978, pp. 107-127.

[6]Evdokimov, Paul, Femeia și mântuirea lumii, prefață de Olivier Clément, trad. Gabriela Moldoveanu, Asociaţia filantropică medicală creştină Christiana, Bucureşti, 1995.

[7]Festugière, André-Jean, La Révélation d'Hermès Trismégiste, vol. 1, Librairie Lecoffre, Paris, 1950.

[8] Filocalia, vol. I, trad., introd. și note de Pr. Prof. Dumitru Stăniloae, Ed. Humanitas, București, 2008.

[9]Filocalia, vol. IV, trad., introd. și note de Pr. Prof. Dumitru Stăniloae, Ed. Humanitas, Bucureşti, 2009.

[10] Filocalia, vol. V, trad., introd. și note de Pr. Prof. Dumitru Stăniloae, Ed. Humanitas, București, 2009.

[11] Filocalia, vol. VI, trad., introd. și note de Pr. Prof. Dumitru Stăniloae, Ed. Humanitas, București, 2008.

[12] Filocalia, vol. VIII, trad., introd. și note de Pr. Prof. Dumitru Stăniloae, Ed. Humanitas, București, 2009.

[13] Filocalia, vol. IX, trad., introd. și note de Pr. Prof. Dumitru Stăniloae, Ed. Humanitas, București, 2011.

[14] Filocalia, vol. X, trad., introd. şi note de Pr. Prof. Dumitru Stăniloae, Ed. Humanitas, București, 2008. 
[15] Filocalia, vol. XII, trad., introd. și note de Pr. Prof. Dumitru Stăniloae, Ed. Humanitas, București, 2009.

[16] Goehring, James E., „The Dark Side of Landscape: Ideology and Power in the Christian Myth of the Desert", în Journal of Medieval and Early Modern Studies, XXXIII (2003), 3, pp. 437-451.

[17] Goehring, James E., „The Encroaching Desert: Literary Production and Ascetic Space in Early Christian Egypt", in: Journal of Early Christian Studies, I (1993), 3, pp. 281-296.

[18] Guillaumont, Antoine, Guillaumont, Claire, „La conception du désert chez les moines d'Egypte”, în Revue de l'Histoire des Religions, CLXXXVIII (1975), pp. 3-21.

[19] Hausherr, Irénée, „Direction spirituelle en Orient autrefois”, în Orientalia Christiana Analecta, CXLIV (1955), 1, Pont. Institutum Orientalium Studiorum, Rome.

[20] Sf. Ioan Casian, Convorbiri duhovnicești, Partea a III-a, XXIV, Convorbirea Pr. Avraam. Despre mortificare, II, în $P S B, 57$, trad. prof. Vasile Cojocaru și prof. David Popescu, Ed. IBMBOR, București, 1990

[21] Laertius, Diogenes, Lives of the Philosophers, ed. A. Robert Caponigri, Regnery, Chicago, 1969.

[22]Lemeni, Adrian, Mihalache, Adrian Sorin (eds.), Realitatea şi Semnificația spațiului, Ed. Basilica, Bucureşti, 2014.

[23] McGuire, Meredith, Lived Religion: Faith and Practice in Everyday Life, NY: Oxford, New York, 2008.

[24] Merton, Thomas, „Dancing in the Water of Life”, in: The Journals of Thomas Merton 5/1963-65, ed. Robert E. Daggy, HarperCollins, San Francisco, 1997.

[25] Pleşu, Andrei, Despre îngeri, Ed. Humanitas, București, 2003.

[26] Regnault, Lucien, Viața cotidiană a Părinţilor deşertului in Egiptul secolului IV, trad. diac. Ioan I. Ică jr, Ed. Deisis, Sibiu, ${ }^{3} 2013$.

[27] Teșu, Pr. Ioan C., Teologia necazurilor și alte înțelesuri, Ed. Christiana, București, 1998.

[28] Ward, Benedicta, Lives of the Desert Fathers: The Historia Monachorum in Aegypto, London and Oxford: Mowbray, 1980

[29] Williams, George, Wilderness and Paradise in Christian Thought: The Biblical Experience of the Desert in the History of Christianity and the Paradise Theme in the Theological Idea of the University, Harper and Bros, New York, 1962. 